UDC 577.112:616

\title{
ERN1 KNOCKDOWN MODIFIES THE HYPOXIC REGULATION OF TP53, MDM2, USP7 AND PERP GENE EXPRESSIONS IN U87 GLIOMA CELLS
}

\author{
S. V. DANILOVSKYI ${ }^{1}$, D. O. MINCHENKO ${ }^{1,2}$, O. S. MOLIAVKO', \\ O. V. KOVALEVSKA ${ }^{1}$, L. L. KARBOVSKYI ${ }^{1}$, O. H. MINCHENKO \\ ${ }^{1}$ Palladin Institute of Biochemistry National Academy of Sciences of Ukraine, Kyiv; \\ e-mail: ominchenko@yahoo.com; \\ ${ }^{2}$ Bogomolets National Medical University, Kyiv, Ukraine
}

\begin{abstract}
Endoplasmic reticulum stress and hypoxia are necessary components of malignant tumors growth and suppression of ERN1 (from endoplasmic reticulum to nuclei-1) signalling pathway, which is linked to the apoptosis and cell death processes, significantly decreases proliferative processes. Glioma cells with ERN1 knockdown were used in order to investigate the effect of ERN1 blockade on the expression of TP53, MDM2, PERP, and USP7 genes and its hypoxic regulation. We have studied the expression of TP53 (tumor protein 53), MDM2 (TP53 E3 ubiquitin protein ligase homolog), PERP (TP53 apoptosis effector), and USP7 (ubiquitin specific peptidase 7) genes, which are related to cell proliferation and apoptosis, in glioma cells with ERN1 knockdown under hypoxic condition. It was shown that blockade of ERN1 gene function in U87 glioma cells intensified the expression of TP53 and USP7 genes, but decreased the expression of MDM2 and PERP genes. Thus, an enhanced expression of TP53 gene in ERN1 knockdown glioma cells correlates with the decreased level of ubiquitin ligase MDM2 and increased expression level of USP7 which deubiquitinates TP53 and MDM2 and induces TP53-dependent cell growth repression and apoptosis. At the same time, the expression levels of TP53, MDM2, and USP7 genes do not change significantly in glioma cells with suppression of endoribonuclease activity only, but PERP gene expression is strongly increased. Moreover, the expression of TP53 and UPS7 genes is decreased in hypoxic conditions in control glioma cells only; however, MDM2 and PERP gene expressions are increased in both cell types, being more significant in ERN1 knockdown cells. Thus, the expression of genes encoding TP53 and related to TP53 factors depends upon the endoplasmic reticulum stress signaling as well as on hypoxia, and correlates with suppression of glioma growth under ERN1 knockdown.
\end{abstract}

Key word s: mRNA expression, TP53, MDM2, USP7, PERP, ERN1, glioma cells, hypoxia.

$\mathrm{E}$ ndoplasmic reticulum stress and hypoxia are necessary components of malignant tumors growth [1-3]. Moreover, the endoplasmic reticulum stress response ERN1 (from endoplasmic reticulum to nuclei-1) signalling pathway is linked to the apoptosis and cell death processes and suppression of its function significantly decreases the glioma growth $[4,5]$. Malignant gliomas are highly aggressive tumors and are characterized by marked angiogenesis, extensive tumor cell invasion into the normal brain parenchyma and to date there is no efficient treatment available. The very poor prognosis and the moderate efficacy of conventional clinical approaches therefore emphasize the need for new therapeutic strategies.
Hypoxia is associated with glioma development and locally induces an adaptive response which provides to tumor cells an enhanced survival and more agressive behaviour. A better knowledge of tumor responses to hypoxia is required to elaborate therapeutical strategies of cell sensibilization based on the blockade of survival mechanisms $[1,4]$. The endoplasmic reticulum is a key organelle in the cell response to hypoxia, ischemia, and chemicals, which activate a complex set of signaling pathways named the unfolded protein response. This adaptive response is activated upon the accumulation of misfolded proteins in the endoplasmic reticulum and is mediated by three endoplasmic reticulum-resident sensors named ERN1, also known as inositol 
requiring enzyme-1, PERK (PRK-like ER kinase), and ATF6 (Activating Transcription Factor 6); however, ERN1 is the dominant sensor of the unfolded protein response to the accumulation of misfolded proteins and represents a key regulator of life and death processes $[1,6,7]$. Misfolded proteins in the endoplasmic reticulum lumen activate two distinct catalytic domains of IRE1, which display serine/ threonine trans-autophosphorylation and endoribonuclease activities, respectively. ERN1-associated endoribonuclease activity is involved in the degradation of a specific subset of mRNA and also initiates the cytosolic splicing of the pre-XBP1 (X-box binding protein 1) mRNA whose mature transcript encodes a transcription factor that stimulates the expression of unfolded protein response specific genes $[2,8]$.

Tumor protein 53 (TP53) coordinates diverse cellular functions through the regulation of the expression of target genes, thereby inducing cell cycle arrest and apoptosis [9]. Despite the intensity of TP53 investigation the molecular mechanisms by which it coordinates diverse cellular functions remain enigmatic. More than 100 physical or genetic interactions with TP53 have been identified to date [9]. The TP53 protein responds to diverse cellular stresses to regulate expression of target genes, thereby inducing cell cycle arrest, apoptosis, senescence, DNA repair, or changes in metabolism. This protein is involved in cell cycle regulation as a trans-activator that acts to negatively regulate cell division by controlling a set of genes required for this process, including an inhibitor of cyclin-dependent kinases, via binding to gene specific response elements, but induction of necrosis by TP53 seems to be largely independent of transcription regulation $[10,11]$.

Activation of TP53 begins through a number of mechanisms including phosphorylation by different protein kinases as well as methylation and acetylation [12]. Phosphorylation of the amino terminus of p53 leads to a conformational change that prevents MDM2 (TP53 E3 ubiquitin protein ligase homolog) binding, resulting in its stabilization and allowing for increased interaction and acetylation by $\mathrm{CBP} /$ p300 which enhance its transcriptional activity [9, 13]. Moreover, the stability as well as functional activity of TP53 depends upon multiple different factors [14-21].

Protein MDM2 is an E3 ubiquitin protein ligase that binds TP53 and targets TP53 for proteasomal degradation, but phosphorylation, cyclin-dependent kinase inhibitor 2A (CDKN2A) and ubiquitin specific peptidase 7 (USP7) prevent MDM2-TP53 interactions, leading to an increase in stable TP53 tetramers in the cytoplasm. Moreover, MDM2 is thought to inhibit TP53 activity in two ways, firstly by ubiquitinating TP53, resulting in its proteasomal degradation, and secondly by binding to a region that prevents the interaction of TP53 with TP300/CBP, thus inhibiting its transcriptional activity. Recently, the inhibition of the interaction between TP53 and MDM2 by a novel Aurora-A-mediated TP53 phosphorylation was identified [22].

The MDM2 oncogene has an important role in human carcinogenesis and various MDM2 inhibitors, including antisense oligonucleotides, siRNA, and small molecule MDM2 inhibitors, have antitumor activity in in vitro and in vivo human cancer models. Interestingly, the antisense MDM2 inhibitors have a broad spectrum of antitumor activities in human cancers, showing the $\mathrm{p} 53$-independent functions of MDM2 [23]. Thus, MDM2 promotes proteasome-dependent ubiquitin-independent degradation of retinoblastoma RB1 protein. Non-degradable ubiquitination of the NOTCH1 receptor by the E3 ubiquitin protein ligase MDM2 which activates the intracellular domain of NOTCH1 and its signalling pathway [24] was recently shown.

The deubiquitinating enzyme USP7 (ubiquitin specific peptidase 7) also known as Herpes virusassociated ubiquitin-specificprotease (HAUSP) is related to cell proliferation and apoptosis because it deubiquitinates TP53 and MDM2 and strongly stabilizes TP53 even in the presence of excess MDM2, and also induces TP53-dependent cell growth repression and apoptosis [25]. Moreover, activity and function of deubiquitinating enzymes, including USP7 enzyme, were regulated via post-translational modifications [26]. Recently it was shown that deubiquitination of K (lysine) acetyltransferase 5 (KAT5) also known as TIP60 by USP7 determines the activity of the TP53-dependent apoptotic pathway in response to genotoxic stress [27]. Moreover, USP7 is a regulator of ubiquitin-conjugating enzyme UbE2E1 in cells as well as together with DAXX regulate mitosis progression and taxane sensitivity by affecting stability of Aurora-A kinase [28, 29]. USP7 is also necessary for PTEN deubiquitination and trafficking in acute myeloid leukemia via interaction with nucleophosmin as well as for NF- $\mathrm{KB}$ deubiquitination and TLRand TNFR-induced transcription activation [30,31].

Protein PERP, an apoptosis-associated target of TP53 tumor suppressor, which is selectively induced 
during apoptosis, and the apoptotic pathway mediated by PERP is a critical mechanism employed by uveal melanoma tumours to modulate susceptibility to apoptosis [32, 33]. Moreover, loss of the TP53 regulated protein PERP promotes tumorigenesis [34]. Recently it was shown that PERP is reduced in human breast cancer cell lines and its deficiency alters mammary gland homeostasis and promotes cancer [35]. Moreover, PERP expression stabilizes active TP53 via modulation of TP53-MDM2 interaction in melanoma cells [36].

The aim of this study was investigation of the effect of ERN1 knockdown on the expression of TP53, MDM2, PERP, and USP7 genes, which related to cell proliferation and apoptosis, and its hypoxic regulation in glioma cells.

\section{Materials and Methods}

Cell Lines and Culture Conditions. The glioma cell line U87 was obtained from ATCC (USA) and grown in high glucose (4.5 g/l) Dulbecco's modified Eagle's minimum essential medium (DMEM; Gibco, Invitrogen, USA) supplemented with glutamine ( $2 \mathrm{mM}$ ), 10\% fetal bovine serum (Equitech-Bio, Inc., USA), penicillin (100 units/ml; Gibco) and streptomycin $\left(0.1 \mathrm{mg} / \mathrm{ml}\right.$; Gibco) at $37{ }^{\circ} \mathrm{C}$ in a $5 \% \mathrm{CO}_{2}$ incubator. In this work we used two sublines of this glioma cell line. One subline was obtained by selection of stable transfected clones with overexpression of vector (pcDNA3.1), which was used for creation of dominant-negative constructs (dnERN1). This untreated subline of glioma cells (control glioma cells) was used as control 1 in the study of effects of hypoxia on the expression level of TP53, MDM2, USP7, and PERP genes. Second subline was obtained by selection of stable transfected clones with overexpression of dnERN1 and suppressed both protein kinase and endoribonuclease activities of this bifunctional sensing and signaling enzyme of endoplasmic reticulum stress. These cells were obtained from prof. M. Moenner (France) [4]. The expression level of studied genes in these cells was compared with cells, transfected by vector (control 1), but the subline which overexpressed dnERN1 was also used as control 2 for investigation of the effect of hypoxia condition on the expression level of these genes under blockade ERN1 function. Hypoxic conditions were created in special incubator with $3 \%$ oxygen and 5\% carbon dioxide levels; culture plates with complete DMEM were exposed to these conditions for $16 \mathrm{hrs}$.
The suppression level of ERN1 both enzymatic activity in glioma cells that overexpress a dominantnegative construct of endoplasmic reticulumnuclei-1 (dnERN1) was previously shown by analysis of the expression of XBP1 alternative splice variant (XBP1s), a key transcription factor in ERN1 signaling, and the level of ERN1 phosphorylated isoform using cells treated by tunicamycin $(0.01 \mathrm{mg} /$ $\mathrm{ml}$ for 2 hours) [37]. Moreover, the proliferation rate of ERN1 knockdown glioma cells is decreased more than twice [4].

The dominant-negative ERN1 endoribonuclease mutant (GenBank accession number JQ425696) was obtained by truncation of the carboxy-terminal 78 amino acids of ERN1. The mutant was obtained by inserting a "GATC" motif at position 2812 of the BglII restriction site -2799-tctgtcagagatc "GATC" tcctccgagccatgagaaataa-2833. The frame shift insertion generates a stop codon 19 bases later. The wild type ERN1 amino acids sequence at positions 896-907 is -SVRDLLRAMRNKand the C-terminal sequence of the mutant is -SVRDRSPPSHEKCOO-. The final sequence was cloned in a pcDNA3.1 plasmid and was controlled by DNA sequencing before transfection in U87 glioma cells. Clones were received by selection at $0.8 \mathrm{mg} / \mathrm{ml}$ G418 (neomycin).

The analysis of ERN1 functional activity in glioma cells that overexpress a dnrERN1 (ERN1 with mutated endoribonuclease) has estimated by determining the expression level of XBP1 alternative splice variant (XBP1s), a key transcription factor in ERN1 signaling, using cells treated by tunicamycin $(0.01 \mathrm{mg} / \mathrm{ml}$ during $2 \mathrm{hrs})$. As shown in Fig. 1, treatment of control (transfected by vector) glioma U87 cells with tunicamycin leads to the formation of an alternative splice variant of XBP1 while in cells transfected by dnrERN1 the alternative splic-

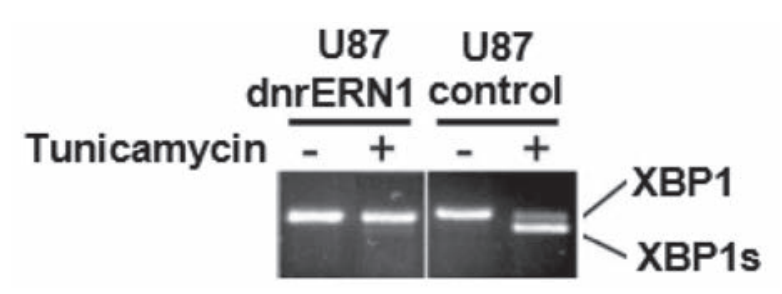

Fig. 1. Effect of tunicamycin $(0.01 \mathrm{mg} / \mathrm{ml}-2 \mathrm{hrs})$ on the mRNA level of transcription factor XBP1 and its alternative splice variant (XBP1s) in glioma U87 cells stable transfected with vector and dnrERN1: reverse-transcriptase-mediated PCR analysis 
ing of XBP1 is completely blocked. Alternative splice variant of XBP1 mRNA is a shorter variant which encodes a longer protein isoform of the transcription factor. Moreover, the proliferation rate of glioma cells with mutated ERN1 endoribonuclease is decreased more than 5 times (Fig. 2). Thus, the blockade of endoribonuclease activity of signaling enzyme ERN1 has more strong effect on proliferation rate of glioma cells than the blockade of both kinase and endoribonuclease activities.

RNA isolation. Total RNA was extracted from glioma cells as previously described [38]. The RNA pellets were washed with $75 \%$ ethanol and dissolved in nuclease-free water. For additional purification RNA samples were re-precipitated with $95 \%$ ethanol and re-dissolved again in nuclease-free water.

Reverse transcription and quantitative PCR analysis. QuaniTect Reverse Transcription Kit (QIAGEN, Germany) was used for cDNA synthesis as described previously [37]. The expression level of TP53, MDM2, USP7, and RERP mRNA were measured in glioma cell line U87 and its subline (clone 1C5) by real-time quantitative polymerase chain reaction using "Mx 3000P QPCR" (Stratagene, USA) and Absolute qPCR SYBRGreen Mix (Thermo Fisher Scientific, ABgene House, UK). Polymerase chain reaction was performed in triplicate.

For amplification of tumor protein 53 (TP53) cDNA we used next primers: forward 5'-GGCCCACTTCACCGTACTAA-3' and reverse 5'-GTGGTTTCAAGGCCAGATGT-3'. The nucleotide sequences of these primers correspond to sequences 1694-1713 and 1849-1830 of human TP53 cDNA (GenBank accession number NM_000546). The size of amplified fragment is $159 \mathrm{bp}$.

The amplification of the cDNA of MDM2 p53 binding protein homolog(MDM2) also known as p53 E3 ubiquitin protein ligase homolog was performed using forward primer (5'-CAGCTTCGGAACAAGAGACC-3') and reverse primer (5'-GTCCGATGATTCCTGCTGAT-3'). These oligonucleotides correspond to sequences 364-383 and 656-637 of human MDM2 cDNA (GenBank accession number NM_002392). The size of amplified fragment is 293 bp.

The amplification of the ubiquitin specific peptidase 7(USP7) also known as Herpes virus-associated ubiquitin-specific protease (HAUSP) cDNA for real time RCR analysis was performed using two oligonucleotides primers: forward - 5'-GTTATAGGGATGGCCCAGGT-3' and reverse - 5'-TCCACG-

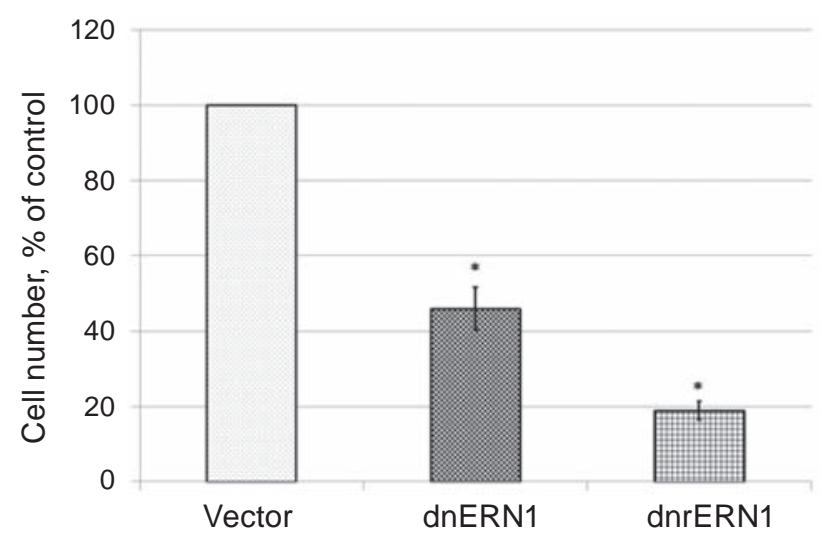

Fig. 2. Proliferation rate of control glioma U87 cells stable transfected with vector (Vector), ERN1 knockdown cells (dnERN1) and glioma cells with blockade only endoribonuclease activity of ERN1 (dnrERN1). Results represented as percent of control (100\%); $n=5 ; * P<0.05$ as compared to control (Vector)

GCCTTTTTACATTC-3'. The nucleotide sequences of these primers correspond to sequences 2730-2749 and 2988-2969 of human USP7 cDNA (GenBank accession number NM_003470). The size of amplified fragment is $259 \mathrm{bp}$.

For amplification of TP53 apoptosis effector (PERP) also known as p53-induced protein (PIGPC1) cDNA we used forward 5'-CATGCTCTTCTGTGGCTTCA-3' and reverse 5'-AAAGCCGTAGGCCCAGTTAT- $3^{\prime}$ primers. The nucleotide sequences of these primers correspond to sequences 420-439 and 648-810 of human PERP cDNA (GenBank accession number NM_022121). The size of amplified fragment is $229 \mathrm{bp}$.

The amplification of $\beta$-actin (ACTB) cDNA was performed using forward - 5'-GGACTTCGAGCAAGAGATGG-3' and reverse - 5'-AGCACTGTGTTGGCGTACAG-3' primers. These primers nucleotide sequences correspond to 747-766 and 980-961 of human ACTB cDNA (GenBank accession number NM_001101). The size of amplified fragment is $234 \bar{b} p$. The expression of $\beta$-actin mRNA was used as control of analyzed RNA quantity. The primers were received from Sigma (USA).

An analysis of quantitative PCR was performed using special computer program Differential Expression Calculator. Statistical analysis was performed according to Student's test using OriginPro 7.5 software. The values of TP53, MDM2, USP7, and PERP mRNA expressions were normalized to the expression of $\beta$-actin mRNA and represented as percent of control $(100 \%)$. All values are expressed as mean \pm 
SEM from triplicate measurements performed in 4 independent experiments.

\section{Results and Discussions}

It was shown that blockade of ERN1 signaling enzyme function in U87 glioma cells has increased the expression of TP53 and USP7 genes $(P<0.05)$, being more significant for TP53 gene (Fig. 3). At the same time, the expression of MDM2 and PERP genes is significantly decreased $(P<0.05)$ in glioma cells with ERN1 knockdown. Thus, an enhanced expression of TP53 gene correlates with a decreased level of ubiquitin ligase MDM2 and increased expression level of USP7 which deubiquitinates TP53 and MDM2 and induces TP53-dependent cell growth repression and apoptosis.

As shown in Fig. 4, the expression level of TP53 gene did not change significantly in glioma cells with suppressed endoribonuclease activity of ERN1 signaling enzyme compared to control glioma cells, but tunicamycin, the inductor of endoplasmic reticulum stress, strongly induced TP53 gene expression $(P<0.05)$ in these glioma cells. Similar result was received with MDM2 gene (Fig. 5). Thus, blockade of ERN1 endoribonuclease activity did not change significantly the expression level of MDM2 gene and tunicamycin also induced its expression $(P<0.05)$, but not too strongly. Moreover, endoribonuclease
ERN1 knockdown did not affect USP7 gene expression; however, tunicamycin had negative effect on USP7 gene expression $(P<0.05)$ in these cells (Fig. 6).

At the same time, the expression level of PERP gene is strongly ( 3 fold; $P<0.05$ ) induced in glioma cells upon blockade of ERN1 endoribonuclease activity (Fig. 7). Moreover, cells with endoribonuclease ERN1 knockdown treated by tunicamycin have shown a decreased level of PERP gene expression compared to non-treated cells.

As shown in Fig. 8, the expression level of TP53 gene is decreased in control glioma cells but was resistant to hypoxic condition in ERN1 knockdown glioma cells. At the same time, hypoxia significantly up-regulated MDM2 gene expression $(P<0.05)$ in both types of glioma cells (Fig. 9). Thus, the effect of hypoxia on the expression of MDM2 gene depends upon blockade of ERN1 endoribonuclease activity. The expression of USP7 and PERP genes are responsible for hypoxia, but in different ways (Fig. 10 and 11). Thus, hypoxia decreased the expression of USP7 gene $(P<0.05)$ and increased the expression of PERP gene $(P<0.05)$ in control glioma cells; however, the blockade of ERN1 signaling enzyme function eliminated the effect of hypoxia on the expression of USP7 gene and enhanced its effect on the expression of PERP gene.

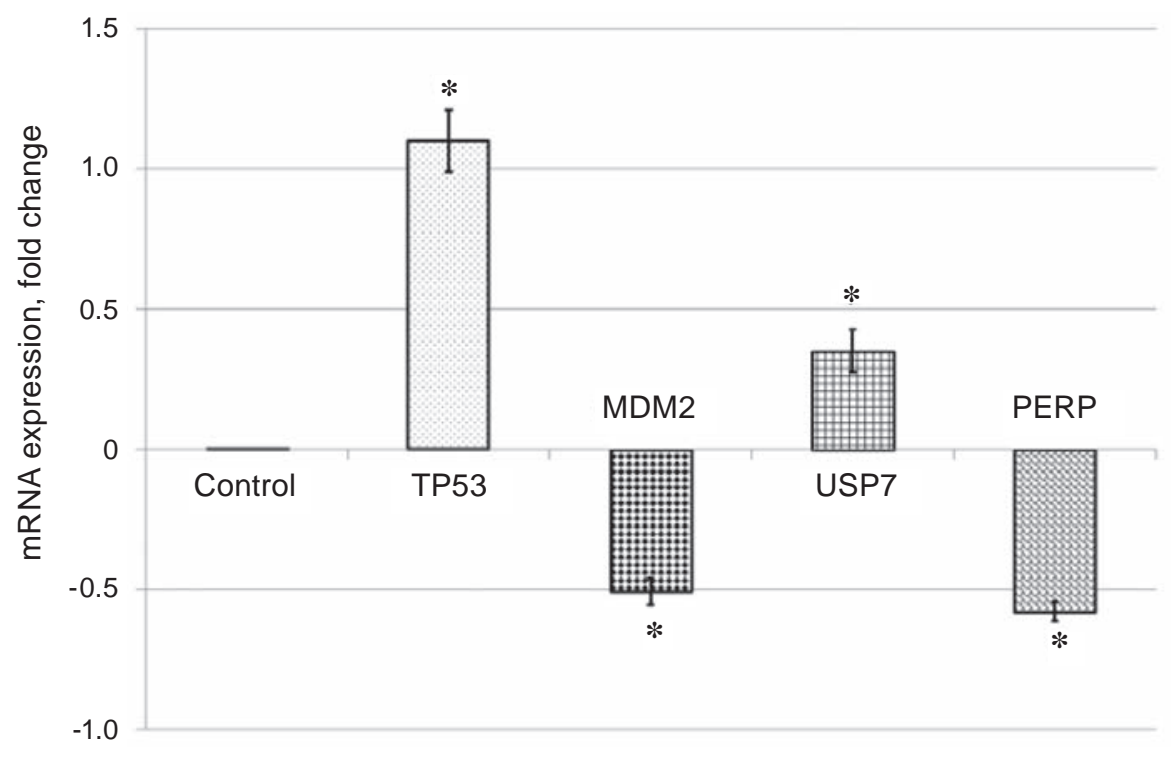

Fig. 3. Expression of TP53, MDM2, USP7, and PERP mRNA in glioma cell line U87, transfected with vector, and its subline with a deficiency of the signaling enzyme ERN1 (dnERN1) measured by qPCR. Values of TP53, MDM2, USP7, and PERP $m R N A$ expressions were normalized to $\beta$-actin $m R N A$ expression and represented as percent of control (100\%); $n=4 ; * P<0.05$ as compared to control (0) 


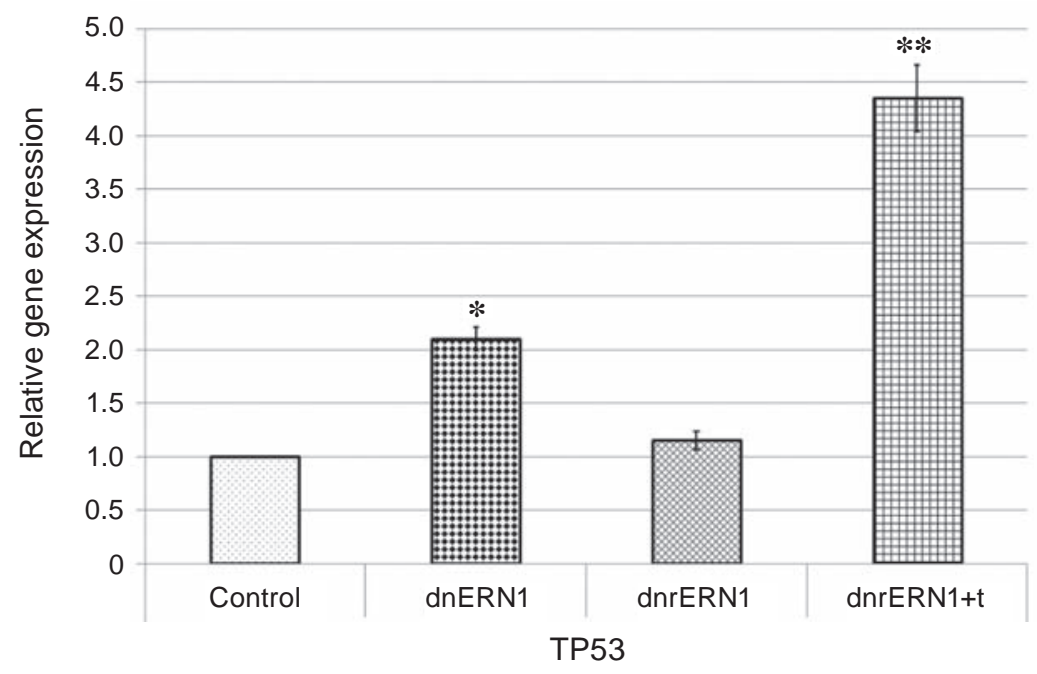

Fig. 4. Expression of tumor protein (TP53) mRNA in glioma cell line U87 (Vector) and its subline with a deficiency of both enzymatic activities of the signaling enzyme ERN1 (dnERN1) or without endoribonuclease activity only (dnrERN1) measured by qPCR. dnrERN1+t - dnrERN1 cells treated by tunicamycin (0.01 mg/ $m l-2$ hrs). Values of TP53 mRNA expressions were normalized to $\beta$-actin $m R N A$ expression and represented as percent of control (100\%); $n=4 ; * P<0.05$ as compared to control; ** $P<0.05$ as compared to dnrERN1

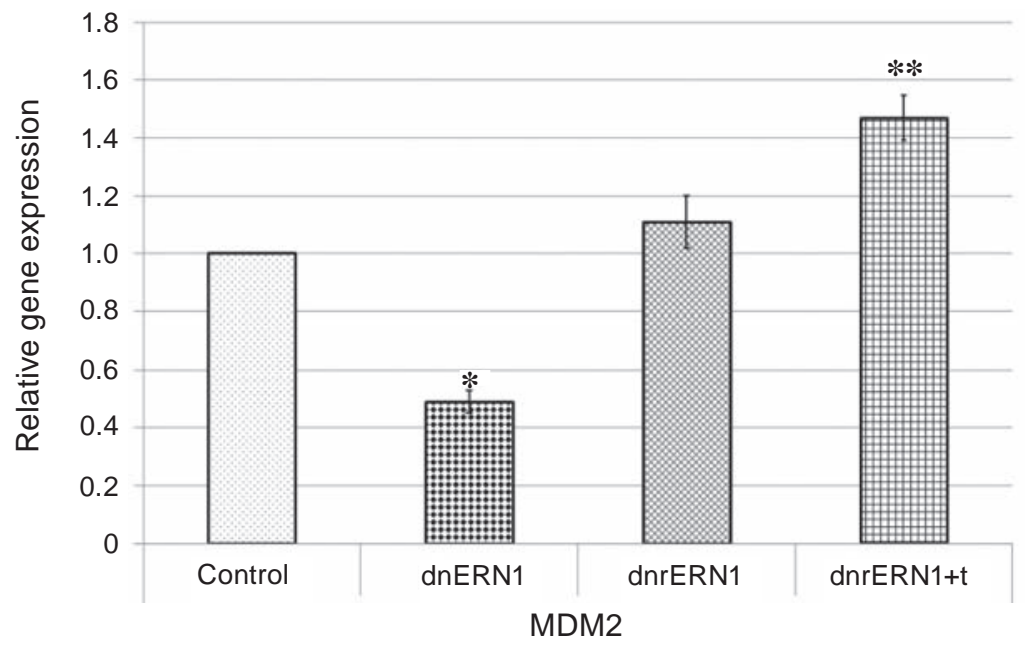

Fig. 5. The expression of MDM2 p53 binding protein homolog (MDM2) mRNA in glioma cell line U87 (Vector) and its subline with a deficiency of both enzymatic activities of the signaling enzyme ERN1 (dnERN1) or without endoribonuclease activity only (dnrERN1) measured by qPCR. dnrERN1+t-dnrERN1 cells treated by tunicamycin $(0.01 \mathrm{mg} / \mathrm{ml}-2 \mathrm{hrs})$. Values of MDM2 $\mathrm{mRNA}$ expressions were normalized to $\beta$-actin $\mathrm{mRNA}$ expression and represented as percent of control (100\%); $n=4 ; * P<0.05$ as compared to control; ** $P<0.05$ as compared to dnrERN1

In this study we have shown that blockade of ERN1 signaling enzyme function in U87 glioma cells affected the expression level of TP53 and TP53relatedgenes in different ways: increased the expression of TP53 and USP7 genes and decreased MDM2 and PERP genes. Thus, an enhanced expression of TP53 gene correlates with a decreased level of ubi- quitin ligase $M D M 2$ and increased expression level of USP7 which deubiquitinates TP53 and MDM2 and induces TP53-dependent cell growth repression and apoptosis. These results agree with data of $[4,5]$ that the suppression of ERN1 signaling enzyme function significantly decreases the glioma growth and that the endoplasmic reticulum stress response 


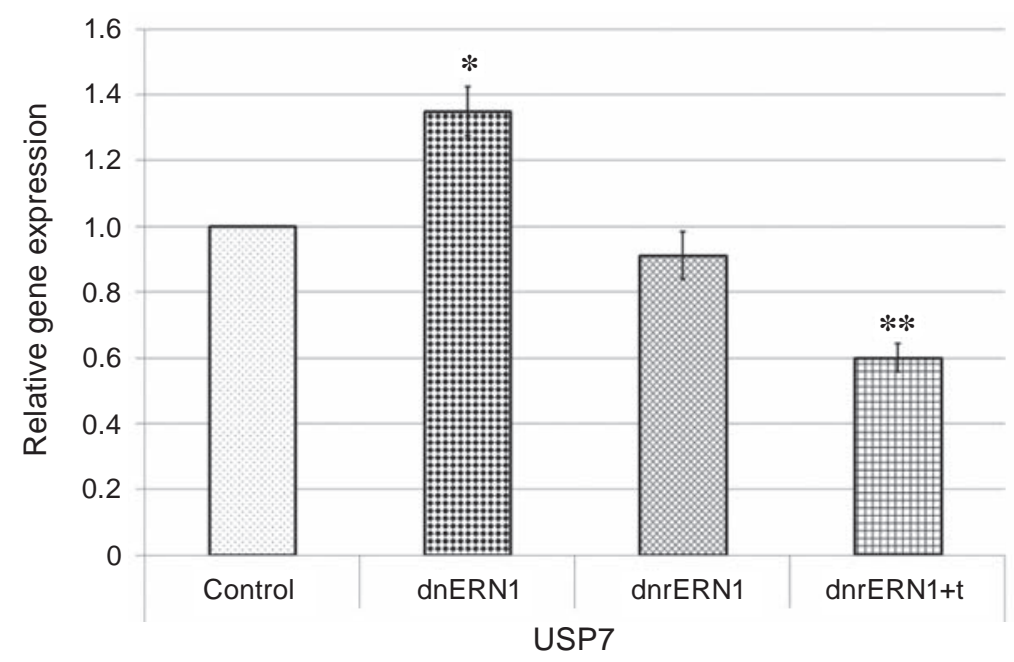

Fig. 6. Expression of ubiquitin specific peptidase 7 (USP7) mRNA in glioma cell line U87 (Vector) and its subline with a deficiency of both enzymatic activities of the signaling enzyme ERN1 (dnERNI) or without endoribonuclease activity only (dnrERN1) measured by qPCR. dnrERN1+t-dnrERN1 cells treated by tunicamycin $(0.01 \mathrm{mg} / \mathrm{ml}-2 \mathrm{hrs})$. Values of USP7 $\mathrm{mRNA}$ expressions were normalized to $\beta$-actin mRNA expression and represented as percent of control (100\%); $n=4 ; * P<0.05$ as compared to control; ** $P<0.05$ as compared to dnrERN1

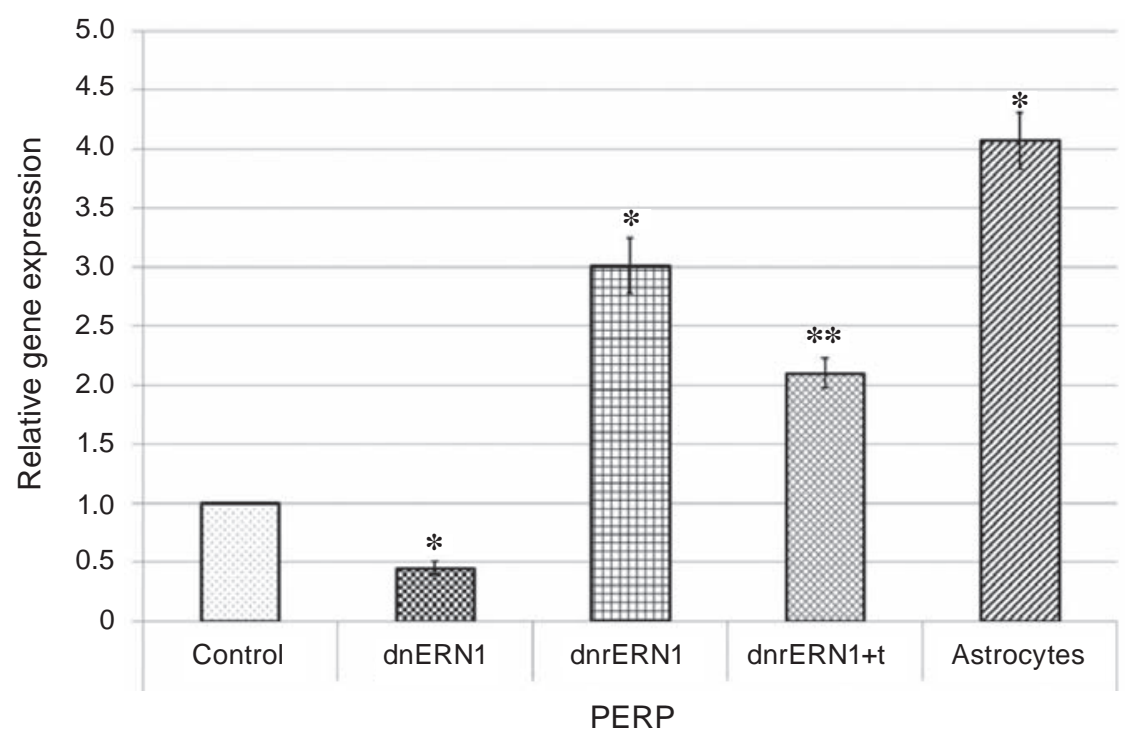

Fig. 7. TP53 apoptosis effector (PERP) mRNA expression in glioma cell line U87 (Vector) and its subline with a deficiency of both enzymatic activities of the signaling enzyme ERN1 (dnERN1) or without endoribonuclease activity only (dnrERN1) measured by qPCR. dnrERN1+t - dnrERN1 cells treated by tunicamycin $(0.01 \mathrm{mg} / \mathrm{ml}-2 \mathrm{hrs})$. Values of PERP $\mathrm{mRNA}$ expressions were normalized to $\beta$-actin $\mathrm{mRNA}$ expression and represented as percent of control (100\%); $n=4 ; * P<0.05$ as compared to control; ${ }^{* *} P<0.05$ as compared to dnrERN1

ERN1 signalling pathway is linked to the apoptosis and cell death processes and is a necessary component of malignant tumors growth [1-3].
However, results of our investigation demonstrate that the expression level of TP53 gene as well as MDM2 and USP7 genes did not change signifi- 


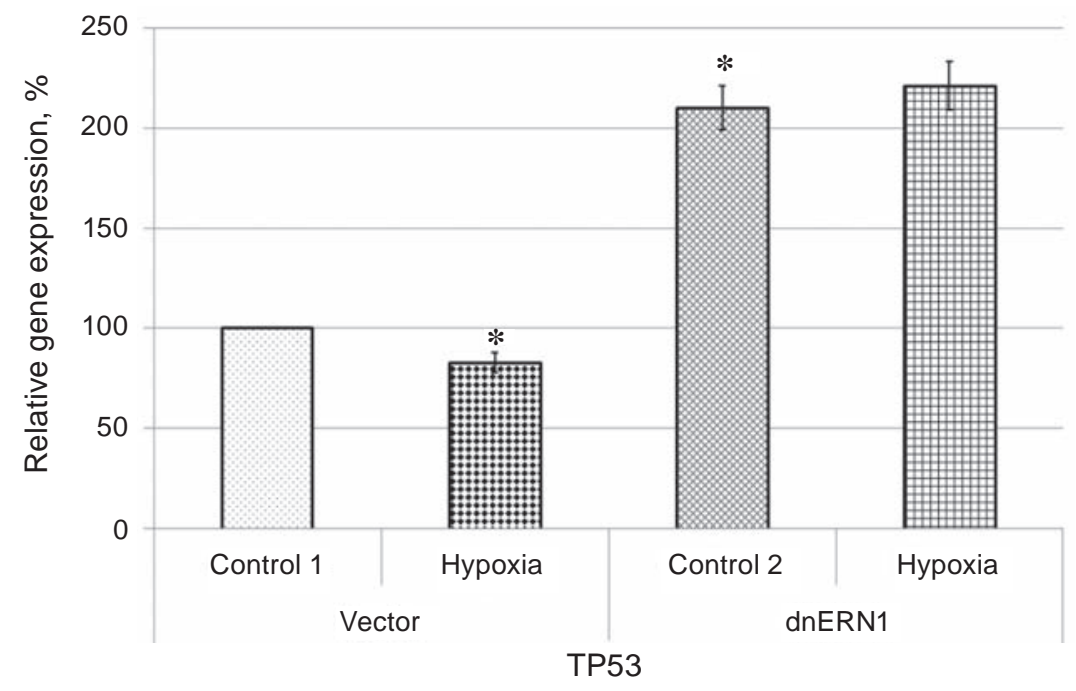

Fig. 8. Effect of hypoxia on the expression of TP53 mRNA in glioma cell line U87 (Vector) and its subline with a deficiency of the signaling enzyme ERN1 (dnERN1) measured by qPCR. Values of TP53 mRNA expressions were normalized to $\beta$-actin $m R N A$ expression and represented as percent of control (100\%); $n=4 ; * P<0.05$ as compared to control 1; ** $\mathrm{P}<0.05$ as compared to control 2

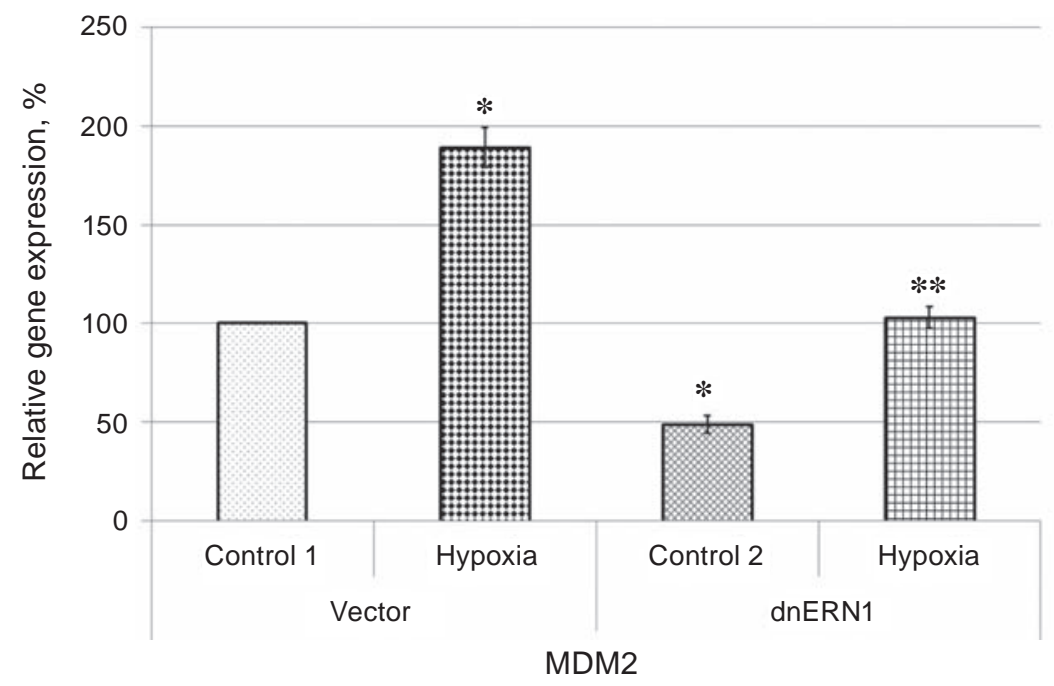

Fig. 9. The expression of MDM2 mRNA in glioma cell line U87 (Vector) and its subline with a deficiency of the signaling enzyme ERN1 (dnERN1): effect of hypoxia. Values of MDM2 mRNA expressions were normalized to beta-actin mRNA expression and represented as percent of control (100\%); $n=4 ; * P<0.05$ as compared to control 1; ** $P<0.05$ as compared to control 2

cantly in glioma cells with suppressed endoribonuclease activity of ERN1 signaling enzyme only compared to control glioma cells. Thus, the changes in the expression level of TP53, MDM2 and USP7 genes in glioma cells with blockade of both enzymatic activities of ERN1 are possibly mediated by ERN1 kinase activity, but not ERN1 endoribonuclease activity. At the same time, the blockade of ERN1 endoribonuclease activity in glioma cells significantly enhances the expression of PERP gene while complete ERN1 knockdown (both enzymatic activities) leads to suppression of this gene expression. We have also shown that the expression level of PERP mRNA in glioma cells is significantly decreased compared to normal human astrocytes and these results correlate with reduced expression of PERP gene in human breast cancer cell lines [35]. Moreover, in glioma cells with ERN1 endoribonu- 


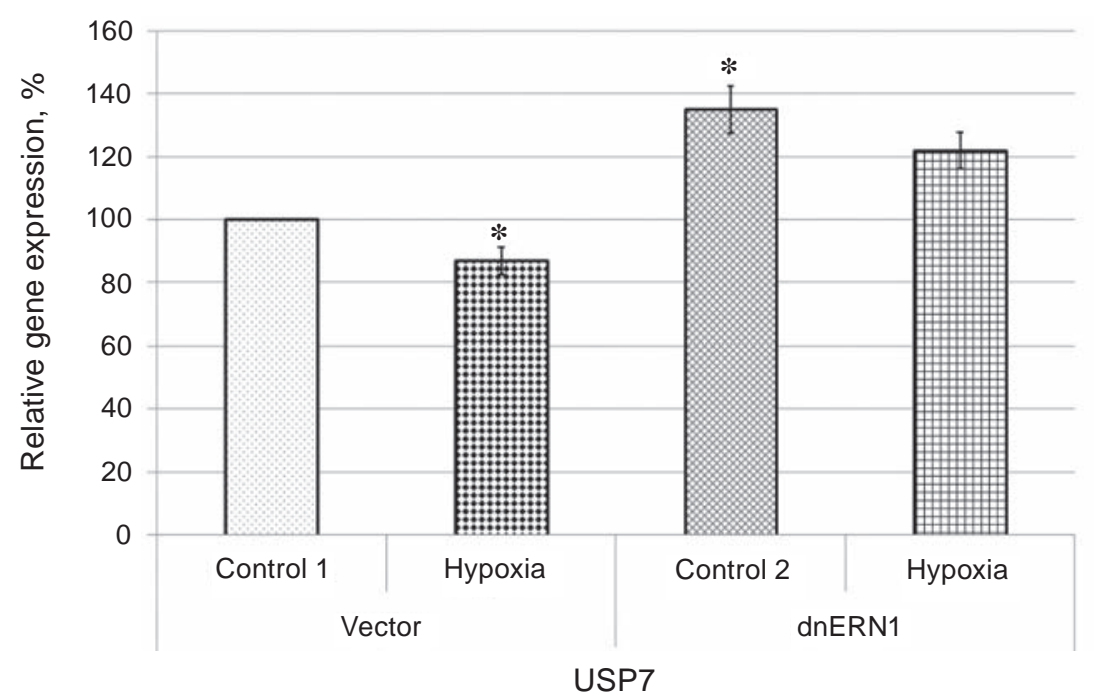

Fig. 10. Effect of hypoxia on the expression of USP7 mRNA in glioma cell line U87 (Vector) and its subline with a deficiency of the signaling enzyme ERN1 (dnERN1) measured by qPCR. Values of USP7 mRNA expressions were normalized to $\beta$-actin $m R N A$ expression and represented as percent of control $(100 \%) ; n=4 ; * P<0.05$ as compared to control $1 ; * * P<0.05$ as compared to control 2

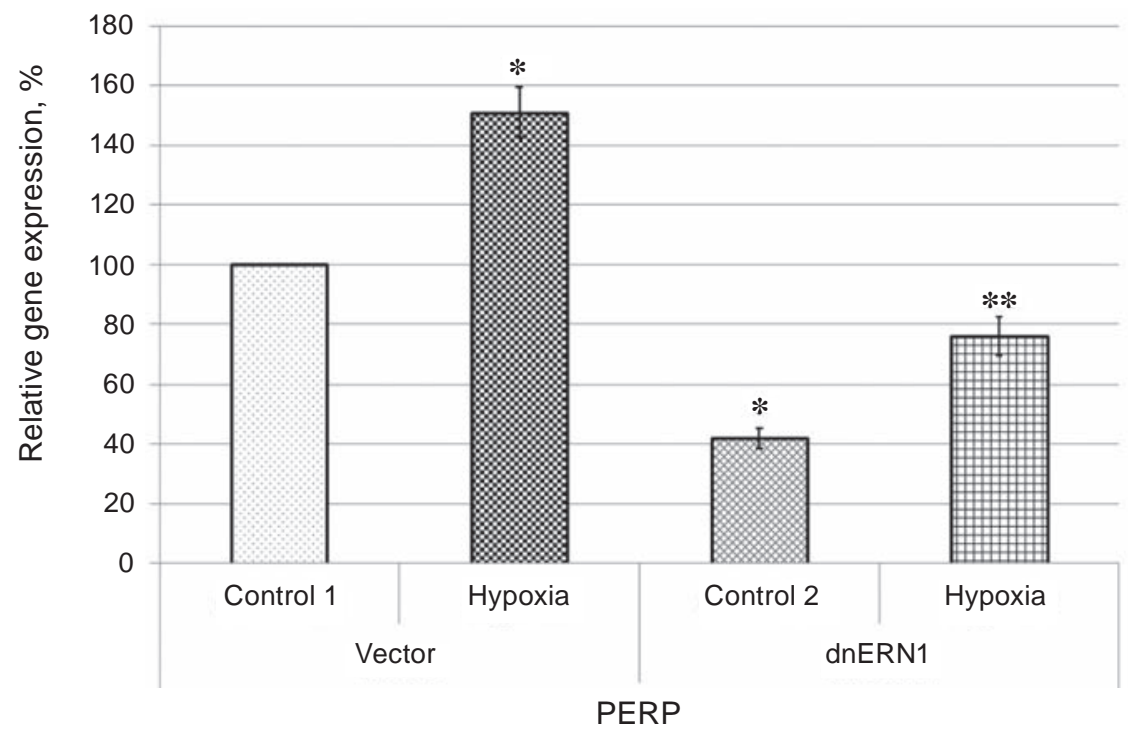

Fig. 11. TP53 apoptosis effector mRNA expression in glioma cell line U87 (Vector) and its subline with a deficiency of the signaling enzyme ERN1 (dnERN1): effect of hypoxia. Values of PERP $m R N A$ expressions were normalized to $\beta$-actin mRNA expression and represented as percent of control (100\%); $n=4 ; * P<0.05$ as compared to control 1; ** $P<0.05$ as compared to control 2

clease knockdown the expression level of PERP gene is increased up to level in normal astrocytes and this data argues with strong suppression of these cells proliferation by stabilization of active TP53 via modulation of TP53-MDM2 interaction [32]. It is possible that both enzymatic activities of ERN1 contribute to the regulation of PERP gene expression. Thus, the exact mechanism of the regulation of
PERP gene expression by ERN1 signaling system requires further investigation.

In this study we have shown that hypoxia affects the expression level of TP53 and TP53-related genes in different ways, being more significant for MDM2 and PERP genes. Thus, hypoxia modifies these gene expressions in control glioma cells but the effect of hypoxia on MDM2 and PERP gene ex- 
pressions depends on ERN1 activity like many other genes $[37,39,40]$.

Results of this investigation clearly demonstrated that the expression of genes encoding TP53, MDM2, USP7, and PERP depended on the endoplasmic reticulum stress signaling via ERN1 enzyme and correlated with suppression of tumor growth. Moreover, the expression of TP53, MDM2, and USP7 genes was not responsible for blockade of ERN1 endoribonuclease activity in glioma cells, but PERP gene is strongly overexpressed in these cells as compared to control glioma cells. Moreover, the blockade of ERN1 endoribonuclease activity increases PERP gene expression close to its level in normal astrocytes. The expression of TP53 and USP7 genes is decreased by hypoxia in control glioma cells only, but MDM2 and PERP gene expressions is increased in both types of glioma cells being more significant in cells with suppressed function of ERN1 signaling enzyme. Thus, the expression of genes encoding TP53 and related to TP53 factors depended on endoplasmic reticulum stress signaling as well as hypoxia and correlate with suppression of glioma growth under ERN1 knockdown.

\section{ПРИГНІЧЕННЯ ЕRN1 МОДИФІКУЄ РЕГУЛЯЦІЮ ЕКСПРЕСІЇ ГЕНІВ ТР53, MDM2, USP7 TA PERP У КЛІТИНАХ ГЛІОМИ ЛІНІї U87 ЗА ГІПОКСІї}

\section{С. В. Даніловський О. С. Молявко ${ }^{1}$, Л. Л. Карбовський О. В. Ковалєвська ${ }^{1}$, О. Г. Мінченко}

$$
\begin{gathered}
{ }^{1} \text { Інститут біохімії ім. О. В. Палладіна } \\
\text { НАН України, Київ; } \\
\text { е-mail: оminchenko@уаһоo.com; } \\
{ }^{2} \text { Національний медичний університет } \\
\text { iм. О. О. Богомольця, Київ, Україна }
\end{gathered}
$$

Стрес ендоплазматичного ретикулума i гіпоксія $є$ необхідними компонентами росту злоякісних пухлин і пригнічення ERN1 (від ендоплазматичного ретикулума до ядра-1) сигнального шляху, який пов'язує апоптоз із процесами смерті клітин, значно зменшує інтенсивність процесів проліферації. Нами досліджено експресію генів TP53 (tumor protein53), MDM2 (TP53 E3 ubiquitin protein ligase homolog), PERP (TP53 apoptosis effector) Ta USP7 (ubiquitin specific peptidase 7), які мають безпосередне відношення до процесів проліферації та апоптозу в клітинах гліоми із пригніченою функцією
ERN1 в умовах гіпоксії. Встановлено, що блокада функції ERN1 у клітинах гліоми лінії U87 посилює експресію генів TP53 та USP7, але зменшує рівень експресії генів MDM2 та PERP. Таким чином, посилена експресія гена TP53 в клітинах гліоми із пригніченою функцією ERN1 повністю узгоджується зі зниженим рівнем експресії убіквітинлігази MDM2 та підвищеним рівнем USP7, яка деубіквітинує TP53 та MDM2, індукуючи, таким чином, ТP53залежну репресію росту пухлинних клітин та їх апоптоз. У той самий час, рівень експресії генів TP53, MDM2 та USP7 у клітинах гліоми iз пригніченою лише ендорибонуклеазною активністю ERN1 істотно не змінюється, але рівень експресії гена PERP при цьому сильно збільшується. Більше того, експресія генів TP53 та UPS7 зменшується за гіпоксії лише в контрольних клітинах гліоми, тоді як експресія генів MDM2 та PERP посилюється в обох типах клітин, хоча значно сильніше в клітинах із пригніченим ERN1. Результати роботи продемонстрували, що експресія генів TP53, MDM2, UPS7 та PERP залежить від сигнального шляху стресу ендоплазматичного ретикулума та гіпоксії і корелює зі зниженням росту гліоми за пригнічення функції ERN1.

К л ю ч о в і с ло в а: експресія мРНК, ТР53, MDM2, USP7, PERP, ERN1, клітини гліоми, гіпоксія.

\section{УГНЕТЕНИЕ ERN1 МОДИФИЦИРУЕТ ГИПОКСИЧЕСКУЮ РЕГУЛЯЦИЮ ЭКСПРЕССИИ ГЕНОВ ТР53, МDМ2, USP7 И РЕRP В КЛЕТКАХ ГЛИОМЫ ЛИНИИ U87}

С. В. Даниловский, Д. А. Минченко ${ }^{1,2}$,

О. С. Молявко ${ }^{1}$ Л. Л. Карбовский

Е. В. Ковалевская ${ }^{1}$, А. Г. Минченко

${ }^{1}$ Институт биохимии им. А. В. Палладина НАН Украины, Киев; e-mail: ominchenko@yahoo.com;

${ }^{2}$ Национальный медицинский университет им. А. А. Богомольца, Киев, Украина

Стресс эндоплазматического ретикулума и гипоксия являются необходимыми компонентами роста злокачественных опухолей и угнетение ERN1 (от эндоплазматического ретикулума к ядру-1) сигнального пути, который связывает 
апоптоз с процессами смерти клеток, значительно уменьшает интенсивность процессов пролиферации. Мы исследовали экспрессию генов TP53 (tumor protein 53), MDM2 (TP53 E3 ubiquitin protein ligase homolog), PERP (TP53 apoptosis effector) и USP7 (ubiquitin specific peptidase 7), которые имеют непосредственное отношение к процессам пролиферации и апоптоза, в клетках глиомы с угнетенной функцией ERN1 при гипоксии. Установлено, что блокада функции ERN1 в клетках глиомы линии U87 усиливает экспрессию генов TP53 и USP7, но снижает уровень экспрессии генов MDM2 и PERP. Таким образом, усиленная экспрессия гена TP53 в клетках глиомы с угнетенной функцией ERN1 полностью согласуется со снижением уровня экспрессии убиквитинлигазы MDM2 и повышением уровня USP7, которая деубиквитинирует TP53 и MDM2, индуцируя, таким образом, TP53зависимую репрессию роста опухолевых клеток и их апоптоз. В то же время, уровень экспрессии генов TP53, MDM2 и USP7 в клетках глиомы с блокадой лишь эндорибонуклеазной активности ERN1 существенно не изменяется, но уровень экспрессии гена PERP при этом сильно увеличивается. Больше того, экспрессия генов ТP53 и UPS7 уменьшается при гипоксии лишь в контрольных клетках глиомы, тогда как экспрессия генов MDM2 и PERP усиливается в обоих типах клеток, хотя значительно сильнее в клетках с подавленной активностью ERN1. Результаты работы продемонстрировали, что экспрессия генов TP53, MDM2, UPS7 и PERP зависит от сигнального пути стресса эндоплазматического ретикулума и гипоксии и коррелирует со снижением роста глиомы при блокаде функции ERN1.

К л ючевы е слова: экспрессия мРНК, TP53, MDM2, USP7, PERP, ERN1, клетки глиомы, гипоксия.

\section{References}

1. Moenner M., Pluquet O., Bouchecareilh M., Chevet $E$. Integrated endoplasmic reticulum stress responses in cancer // Cancer Res. 2007. - 67, N 22. - P. 10631-10634.

2. Schröder $M$. Endoplasmic reticulum stress responses // Cell. Mol. Life Sci. - 2008. - 65, N 6. - P. 862-894.
3. Wang S., Kaufman R. J. The impact of the unfolded protein response on human disease // J. Cell. Biol.- 2012. - 197, N 7. - P. 857-887.

4. Auf G., Jabouille A., Guerit S., Pineau R., Delugin M., Bouchecareilh M., Favereaux A., Maitre M., Gaiser T., von Deimling A., Czabanka M., Vajkoczy P., Chevet E., Bikfalvi A. Moenner $M$. A shift from an angiogenic to invasive phenotype induced in malignant glioma by inhibition of the unfolded protein response sensor IRE1 // Proc. Natl. Acad. Sci. USA. 2010. - 107, N 35. - P. 15553-15558.

5. Drogat B., Auguste P., Nguyen D. T., Bouchecareilh M., Pineau R., Nalbantoglu J., Kaufman R. J., Chevet E., Bikfalvi A., Moenner M. IRE1 signaling is essential for ischemia-induced vascular endothelial growth factor-A expression and contributes to angiogenesis and tumor growth in vivo // Cancer Res. - 2007. - 67, N 14. - P. 6700-6707.

6. Schröder M., Kaufman R. J. The mammalian unfolded protein response // Annu. Rev. Biochem. - 2005. - 74. - P. 739-789.

7. Zhang K., Kaufman R. J. The unfolded protein response: a stress signaling pathway critical for health and disease // Neurology. - 2006. - 66, N 2 (Suppl. 1). - P. S102-S109.

8. Hollien J., Lin J. H., Li H., Stevens N., Walter P., Weissman J. S. Regulated Ire1-dependent decay of messenger RNAs in mammalian cells // J. Cell. Biol. - 2009. - 186, N 3. - P. 323-331.

9. Mills K. D. Tumor suppression: putting p53 in context // Cell Cycle. - 2013. - 12, N 22. P. 3461-3462.

10. Golubovskaya V. M., Cance W. G. Targeting the p53 pathway // Surg. Oncol. Clin. N. Am. 2013. - 22, N 4. - P. 747-764.

11. Dent $P$. Non-canonical p53 signaling to promote invasion // Cancer Biol. Ther. - 2013. - 14, N 10. - P. 879-880.

12. Lee S. K., Kim Y. S. Phosphorylation of eIF2 $\alpha$ attenuates statin-induced apoptosis by inhibiting the stabilization and translocation of $\mathrm{p} 53$ to the mitochondria // Int. J. Oncol. - 2013. - 42, N 3. P. 810-816.

13. Chen D., Zhang J., Li M., Rayburn E. R., Wang H., Zhang R. RYBP stabilizes p53 by modulating MDM2 // EMBO Rep. - 2009. - 10, N 2. - P. 166-172. 
14. Shahbazi J., Lock R., Liu T. Tumor protein 53-induced nuclear protein 1 enhances p53 function and represses tumorigenesis // Front. Genet. - 2013. - 4. - P. 80.

15. Thomas S. E., Malzer E., Ordonez A., Dalton L. E., van't Wout E. F., Liniker E., Crowther D. C., Lomas D. A., Marciniak S. J. p53 and translation attenuation regulate distinct cell cycle checkpoints during ER stress // J. Biol. Chem. - 2013. - 288, N 11. - P. 7606-7617.

16. Yang X., Li H., Zhou Z., Wang W. H., Deng A., Andrisani O., Liu X. Plk1-mediated phosphorylation of Topors regulates p53 stability // J. Biol. Chem. - 2009. - 284, N 28. - P. 1858818592.

17. Budanov A. V., Karin M. p53 target genes sestrin1 and sestrin 2 connect genotoxic stress and mTOR signaling // Cell. - 2008. - 134, N 3. - P. 451-460.

18. Shinbo Y., Taira T., Niki T., Iguchi-Ariga S. M., Ariga $H$. DJ-1 restores p53 transcription activity inhibited by Topors/p53BP3 // Int. J. Oncol. 2005. - 26, N 3. - P. 641-648.

19. Weger S., Hammer E., Heilbronn R. Topors acts as a SUMO-1 E3 ligase for p53 in vitro and in vivo // FEBS Lett. - 2005. - 579, N 22. P. 5007-5012.

20. Velasco-Miguel S., Buckbinder L., Jean P., Gelbert L., Talbott R., Laidlaw J., Seizinger B., Kley $N$. PA26, a novel target of the p53 tumor suppressor and member of the GADD family of DNA damage and growth arrest inducible genes // Oncogene. - 1999. - 18, N 1. - P. 127-137.

21. Apostolidis P. A., Lindsey S., Miller W. M., Papoutsakis E. T. Proposed megakaryocytic regulon of $\mathrm{p53}$ : the genes engaged to control cell cycle and apoptosis during megakaryocytic differentiation // Physiol. Genomics. - 2012. 44, N 12. - P. 638-650.

22. Hsueh K. W., Fu S. L., Chang C. B., ChangyY. L., Lin C. H. A novel Aurora-A-mediated phosphorylation of p53 inhibits its interaction with MDM2 // Biochim. Biophys.Acta. - 2013. 1834, N 2. - P. 508-515.

23. Zhang Z., Zhang Z., Cheng J., Li M., Wang W., $X u$ W., Wang H., Zhang $R$. Transcription factor NFAT1 activates the mdm2 oncogene independent of p53 // J. Biol. Chem. - 2012. 287, N 36. - P. 30468-30476.

24. Pettersson S., Sczaniecka M., McLaren L. Nondegradative ubiquitination of the Notch1 receptor by the E3 ligase MDM2 activates the Notch signalling pathway // Biochem. J. - 2013. - 450, N 3. - P. 523-536.

25. Nicholson B., Suresh Kumar K. G. The multifaceted roles of USP7: new therapeutic opportunities // Cell. Biochem. Biophys. 2011. - 60, N 1-2. - P. 61-68.

26. Kessler B. M., Edelmann M. J. PTMs in conversation: activity and function of deubiquitinating enzymes regulated via posttranslational modifications // Cell. Biochem. Biophys. - 2011. - 60, N 1-2. - P. 21-38.

27. Dar A., Shibata E., Dutta A. Deubiquitination of Tip60 by USP7 determines the activity of the p53-dependent apoptotic pathway // Mol. Cell. Biol. - 2013. - 33, N 16. - P. 3309-3320.

28. Sarkari F., Wheaton K., La Delfa A., Mohamed M., Shaikh F., Khatun R., Arrowsmith C. H., Frappier L., Saridakis V., Sheng Y. Ubiquitinspecific protease 7 is a regulator of ubiquitinconjugating enzyme UbE2E1 // J. Biol. Chem. 2013. - 288, N 23. - P. 16975-16985.

29. Giovinazzi S., Morozov V. M., Summers M. K., Reinhold W. C., Ishov A. M. USP7 and Daxx regulate mitosis progression and taxane sensitivity by affecting stability of Aurora-A kinase // Cell Death Differ. - 2013. - 20, N 5. P. 721-731.

30. Noguera N. I., Song M. S., Divona M., Catalano G., Calvo K. L., García F., Ottone T., Florenzano F., Faraoni I., Battistini L., Colombo E., Amadori S., Pandolfi P. P., LoCoco F. Nucleophosmin/B26 regulates PTEN through interaction with HAUSP in acute myeloid leukemia // Leukemia. - 2013. - 27, N 5. - P. 1037-1043.

31. Colleran A., Collins P. E., O'Carroll C., Ahmed A., Mao X., McManus B., Kiely P. A., Burstein E., Carmody R. J. Deubiquitination of NF- $\kappa$ B by Ubiquitin-Specific Protease-7 promotes transcription // Proc. Natl. Acad. Sci. USA. - 2013. - 110, N 2. - P. 618-623.

32. Davies L., Gray D., Spiller D., White M. R., Damato B., Grierson I., Paraoan L. P53 apoptosis mediator PERP: localization, functionn and caspase activation in uveal melanoma // J. Cell. Mol. Med. - 2009. - 13, N 8B. - P. 1995-2007.

33. Ihrie R. A., Attardi L. D. Perp-etrating p53dependent apoptosis // Cell Cycle. - 2004. - 3, N 3. - P. 267-269.

34. Beaudry V. G., Jiang D., Dusek R. L., Park E. J., Knezevich S., Ridd K., Vogel H., 
Bastian B. C., Attardi L. D. Loss of the p53/p63 regulated desmosomal protein Perp promotes tumorigenesis // PLoSGenet. - 2010. - 6, N 10. P. E1001168.

35. Dusek R. L., Bascom J. L., Vogel H., Baron S., Borowsky A. D., Bissell M. J., Attardi L. D. Deficiency of the p53/p63 target Perp alters mammary gland homeostasis and promotes cancer // Breast Cancer Res. - 2012. - 14, N 2. P. R65.

36. Davies L., Spiller D., White M. R., Grierson I., Paraoan L. PERP expression stabilizes active p53 via modulation of $\mathrm{p} 53-\mathrm{MDM} 2$ interaction in uveal melanoma cells // Cell Death Dis. - 2011. 2. - P. e136.

37. Minchenko D. O., Kubajchuk K.I., Ratushna O. O., Komisarenko S. V., Minchenko O. H. The effect of hypoxia and ischemic condition on the expression of VEGF genes in glioma U87 cells is dependent from ERN1 knockdown // Adv. Biol. Chem. - 2012. - 2, N 2. - P. 198-206.
38. Minchenko O. H., Opentanova I. L., Minchenko D. O., Ogura T., Esumi H. Hypoxia induces transcription of 6-phosphofructo-2-kinase/ fructose-2,6-bisphosphatase 4 gene via hypoxiainducible factor-1alpha activation // FEBS Lett. 2004. - 576, N 1-2. - P. 14-20.

39. Minchenko D. O., Karbovskyi L. L., Danilovskyi S. V., Kharkova A. P., Minchenko O. H. Expression of casein kinase genes in glioma cell line U87: effect of hypoxia and glucose or glutamine deprivation // Nat. Sci. - 2012. - 4, N 1. - P. 38-46.

40. Minchenko D. O., Karbovskyi L. L., Danilovskyi S. V., Moenner M., Minchenko O. H. Effect of hypoxia and glutamine or glucose deprivation on the expression of retinoblastoma and retinoblastoma-related genes in ERN1 knockdown glioma U87 cell line // Am. J. Mol. Biol. - 2012. - 2, N 1. - P. 21-31.

Received 04.12.2013 